\title{
SENSORIAMENTO REMOTO APLICADO AO MAPEAMENTO DA DINÂMICA DO USO DO SOLO NA BACIA DO RIO PACUÍ, NO NORTE DE MINAS GERAIS, NOS ANOS DE 1989, 1999 E 2009
}

\author{
Marcos Esdras Leite ${ }^{1}$ \\ Maria Ivete Soares de Almeida ${ }^{2}$ \\ Gabriel Alves Veloso ${ }^{3}$ \\ Maykon Fredson Freitas Ferreira ${ }^{4}$
}

Resumo: A mesorregião do Norte de Minas Gerais apresenta um clima com concentração das chuvas no verão, logo há escassez pluviométrica na maior parte do ano. Com isto, a oferta de água superficial é comprometida, o que torna o recurso hídrico um tema de conflito e de interesse público. A bacia do rio Pacuí é um caso típico de conflito ambiental instalado, pois o uso do solo faz com que a oferta da água seja desigual ao longo da bacia. Neste contexto, este trabalho buscou analisar ao longo das últimas duas décadas, através de imagens de satélite, a dinâmica no uso do solo da bacia do rio Pacuí. Este rio é afluente da margem direita do Rio São Francisco e atinge nove municípios norte-mineiros. Com o procedimento metodológico baseado em monitoramento remoto e trabalho de campo foi possivel identificar a redução significativa da vegetação natural e o aumento considerável na área de pastagem, no decorrer do período analisado.

Palavras-Chave: Sensoriamento remoto; SIG; Bacia hidrográfica; Pacuí.

\section{REMOTE SENSING APPLIED TO MAPPING THE DYNAMICS OF LAND USE IN THE PACUÍ RIVER BASIN IN NORTHERN MINAS GERAIS, FROM 1989, 1999 AND 2009}

\begin{abstract}
The North of Minas Gerais has a concentration of climate with summer rains, so there is a shortage of rainfall in most years. Thus, the supply of surface water is compromised, which makes the subject of a water resource conflict and public interest. The Pacui River Basin is a typical case of environmental conflict installed because the land use makes the supply of water is uneven across the basin. In this context, this study was to examine over the past two decades, through satellite images, the dynamics of land use Pacui River Basin. This river is a tributary on the right bank of the São Francisco river and reaches nine counties north-miners. With the methodological procedure based on remote monitoring and field work was possible to identify the significant reduction of natural vegetation and a considerable increase in pasture area during the period analyzed.
\end{abstract}

Key-Words: Remote sensing; GIS; River Basin; River Pacuí.

\footnotetext{
${ }^{1}$ Graduação em Geografia, Mestre em Geografia, Professor Doutor, Coordenador do Laboratório de Geoprocessamento da Universidade Estadual de Montes Claros/UNIMONTES. Bolsista de produtividade FAPEMIG - E-mail: marcosesdras@ig.com.br

${ }^{2}$ Graduação em Geografia, Mestrado em Geografia, Doutorado (Doutorando) em Geografia, Vice-reitora da Unimontes da Universidade Estadual de Montes Claros/UNIMONTES._E-mail: ivetegeo@yahoo.com.br.

${ }^{3}$ Graduação em Geografia pela Universidade Estadual de Montes Claros/UNIMONTES. Mestrando Geografia pela Universidade Federal de Uberlândia - Email: gabrielveloso38@yahoo.com.br

${ }^{4}$ Graduação em Geografia pela Universidade Estadual de Montes Claros/UNIMONTES - E-mail: maykonfredson@gmail.com DOI: 10.7154/RDG.2012.0023.0009
} 


\section{INTRODUÇÃO}

No norte de Minas Gerais importantes atividades humanas são desenvolvidas em áreas onde antes se encontrava apenas vegetação natural. Estes vulneráveis compartimentos naturais são atingidos por atividades antrópicas sem precedentes, que são evidenciados, preponderantemente, por áreas desmatadas, destinadas, em grande parte, para pastagem, agricultura e silvicultura. Diante dessa estrutura, diversos impactos negativos são percebidos na bacia hidrográfica do rio Pacuí que, em suma, envolvem, primordialmente, os recursos hídricos e o uso da água.

Não há dúvida de que a água é um recurso básico para a manutenção da vida no planeta Terra. Assim, a água é um elemento fundamental para o bom funcionamento do ecossistema, colaborando, diretamente, para formação de florestas e manutenção da biodiversidade, sendo de grande importância para o desenvolvimento econômico e social. Portanto, a escassez deste recurso pode gerar um empecilho ao desenvolvimento (TUNDISI, 2005).

Nesse sentido, a conservação da qualidade e quantidade da água, bem como a sua distribuição de forma igualitária, é fundamental para a boa qualidade de vida humana, sendo um requisito importante para indicar melhores índices sociais e econômicos. Diante disso, salienta-se que o equilíbrio hídrico está vinculado essencialmente, ao nível de preservação das bacias hidrográficas, pelas quais perpassam as principais atividades de utilidade hídrica.

Portanto, as concepções teóricas, nas quais se baseou esta análise, configuram-se na formulação de conceitos que compreendem as relações ambientais como uma estrutura sistêmica, em que qualquer alteração em uma parte do sistema implicará na alteração de outras partes e, consequentemente, no todo.

Um sistema, segundo Christofoletti (1974), pode ser definido como o conjunto dos elementos e das relações entre si e seus atributos. Este se baseia na concepção de totalidades integradas, que resultam das interações e interdependências de suas partes e se manifestam por meio de uma natureza, intrinsecamente, dinâmica e flexível.

A partir desses fundamentos, as bacias hidrográficas se enquadram em concepções sistêmicas, visto que estas trabalham de forma integrada, conforme sua série de depósitos e suas águas correntes. Entretanto, quando há uma ação na transferência da superfície ou do 
solo, ou em armazenagens, provavelmente uma reação em cadeia provocará mudanças em todos os outros depósitos e transferências, interferindo na composição sistêmica da bacia hidrográfica (CUNHA; GUERRA, 2000).

Nesse sentido, estudar a bacia hidrográfica com a finalidade de analisar os impactos ambientais e levantar dados referentes à origem dos mesmos é viável, uma vez que existe a possibilidade de uma visão integrada dos elementos nela presente. Ela se constitui num sistema aberto que possui fluxos de energias das forças climáticas, as quais atuam sobre sua área e perdem energias por meio da água, dos sedimentos e materiais em solução, até seu ponto de saída. Isso facilita as análises das interações dos elementos abióticos, bióticos e antrópicos (CHORLEY, 1962 apud CUNHA; GUERRA, 1996).

Diante dos danos ao meio ambiente, em especial aos recursos hídricos, a gestão de forma integrada em bacias hidrográficas é necessária, uma vez que possibilita melhor atendimento às necessidades da sociedade. Assim, minimizar os impactos ao meio ambiente, através da gestão e planejamento das Bacias Hidrográficas, se tornou essencial, principalmente a partir da Conferência das Nações Unidas sobre Meio Ambiente e Desenvolvimento, realizada no Rio de Janeiro, em 1992. As discussões nesta Conferência resultaram na aprovação da Agenda 21, documento que consagra os mais elevados princípios de defesa da biodiversidade e dos recursos naturais da Terra (NOVAES et al., 2000).

Diante dessa abordagem, para obter resultados relevantes e dados confiáveis das condições dos ambientes naturais e físicos das bacias hidrográficas, procura-se desenvolver análises provenientes da evolução do uso e ocupação do solo. A partir daí, as situações que originam a degradação ambiental se tornam perceptíveis, auxiliando na tomada de decisão e possíveis soluções.

Para tanto, as análises de uso do solo dispõe de importantes instrumentos dentro das geotecnologias que possibilitam a geração de valorosas informações espaciais e temporais, diagnósticos e prognósticos que são relevantes em análises naturais.

O sensoriamento remoto, técnica que compõe as geotecnologias, surgiu com a finalidade de monitorar determinado espaço à distância, o que possibilita uma maior eficácia em estudos ambientais. O sensoriamento remoto é uma tecnologia para captação de informações de um alvo, através da radiação eletromagnética, gerada por fontes naturais ou artificiais (ROSA, 1995). A função principal de um sistema de sensoriamento remoto é a obtenção de uma imagem do alvo, o que possibilita ao usuário extrair informações. Essa definição é 
semelhante à de McCloy (2005, p.27) "sensoriamento remoto é definido como a aquisição de dados usando um dispositivo de monitoramento localizado à distância para extração de informação do objeto".

Além do sensoriamento remoto, também é utilizado o Sistema de Informação Geográfica (SIG) que é destinado ao tratamento de dados georeferenciados. Desta maneira, tratam-se de tecnologias para a aquisição, armazenamento, gerenciamento, análise e exibição de dados espaciais (ROSA, 1995). Diante dessas funções o SIG pode ser trabalhado conjuntamente com as análises das imagens orbitais.

A partir dessas considerações o objetivo deste trabalho foi analisar, nos de 1989, 1999 e 2009, o uso do solo na bacia hidrográfica do rio Pacuí, no norte de Minas Gerais, com a finalidade de monitorar a dinâmica da ocupação humana e a retirada da vegetação natural. Para se chegar ao objetivo desejado, foi imprescindível o uso de imagens de sensores orbitais, pois somente desta maneira foi possível fazer uma série temporal com uma incursão histórica de vinte anos para monitorar a ocupação da bacia do rio Pacuí, nos anos de 1989, 1999 e 2009.

\section{MATERIAIS E METÓDOS}

A análise do uso do solo em bacias hidrográficas envolve uma série de procedimentos tecnológicos e metodológicos, quando se usa as técnicas de Sensoriamento Remoto e de Sistema de Informação Geográfica (SIG). Através desses procedimentos foi realizado um estudo do uso do solo na bacia do rio Pacuí, nos anos de 1989, 1999 e 2009, o qual permitiu analisar a influência das atividades antrópicas na bacia supracitada, principalmente no que se refere aos cursos da água. Esta metodologia foi dividida em etapas operacionais que se integraram no final do procedimento metodológico.

Dessa maneira, a primeira etapa do trabalho consistiu na pesquisa bibliográfica de obras que discutem sobre o uso das geotecnologias no monitoramento de bacias hidrográficas e de autores que estudam sobre a água como recurso natural de extrema relevância para a vida do homem e da Terra. Na sequência, buscou-se no sítio da Empresa Brasileira de Pesquisas Agropecuárias (Embrapa), a imagem Shuttle Radar Topographic Mission (SRTM), a carta de 1: 250.000 SE-23-X-A, na qual foi utilizado o software ArcGis Map 9.3 para delimitação da bacia do rio Riachão. 
Em seguida, foram adquiridos os dados orbitais no Instituto Nacional de Pesquisas Espaciais (INPE). As imagens empregadas são provenientes do sensor TM do Satélite LandSat 5. Esses produtos apresentam resolução espacial de 30 metros no pancromático, além da disponibilidade de 7 bandas espectrais. Utilizou-se as bandas 3, 4 e 5 da órbita 218 e 219 dos pontos 70 e 71 das imagens LandSat 5 TM. No software Spring 5.0.6 as imagens foram tratadas, gerando a composição multiespectral. Dessa forma, a composição colorida resultante foi a banda 3 no verde, a banda 4 no vermelho e a banda 5 no azul.

Realizada a composição, empregou-se o registro das imagens que é um reposicionamento das imagens, no qual se utiliza como base o arquivo em formato shp de hidrografia do Instituto Mineiro de Gestão das Águas (IGAM). Posteriormente, foi gerado o mosaico, que foi recortado pelo limite da bacia do rio Pacuí.

Para subsidiar o processo de classificação foi realizado trabalho de campo ao longo de toda área da bacia para identificar os usos do solo presentes na mesma. Como suporte foram coletados dados, através de aparelho receptor do sistema GPS. Ao longo da visita a campo, foram registrados 110 pontos de coordenadas para controle do uso do solo.

Em laboratório, com a imagem recortada, foi utilizado o procedimento de vetorização das máscaras no software ArcGis Map 9.3 para diminuir o nível de confusão entre as classes de uso do solo e, consequentemente, obter melhor resultado na classificação supervisionada, sendo vetorizadas, como máscaras, as classes de eucalipto e cultivo.

Seguindo a ordem operacional, as imagens foram classificadas, utilizando a técnica de classificação supervisionada, que é baseada no uso de algoritmos para se determinar os pixels que representam valores de reflexão característicos para uma determinada classe. Para tanto, utilizou-se, neste trabalho, o classificador MAXVER.

Para classificar a imagem foram escolhidas as classes de uso do solo: vegetação natural, eucalipto, mata ciliar e outros. Nesta última, foram englobados as classes de pastagem, pastagem degradada e solo exposto. Isto, devido ao grau de confusão da resposta espectral dessas classes.

Para validar os dados obtidos pelos sensores orbitais foi necessária uma nova visita à área da bacia. Nesse segundo trabalho de campo, o resultado da classificação de 2009 foi conferido com os usos da terra no local. Com esse procedimento, percebeu-se que a classificação das imagens e, consequentemente, o mapeamento de uso da terra obteve resultado satisfatório. 
Realizada a classificação final das imagens, os dados foram convertidos de Matriz para Vetor, onde foi feito o cálculo da área de cada classe de uso do solo em quilômetros quadrados. Estes foram tabulados em gráficos, possibilitando a análise da dinâmica da bacia.

Finalizando o procedimento metodológico, foram elaborados mapas temáticos de uso do solo na bacia do rio Pacuí, o que facilitou a leitura de como essa área está sendo utilizada.

\section{A Área De Estudo}

A bacia hidrográfica do rio Pacuí está localizada na Mesorregião Norte do estado de Minas Gerais, entre as coordenadas geográficas $16^{\circ} 10^{\prime} 35^{\prime \prime}$ e $16^{\circ} 54^{\prime} 57^{\prime \prime}$ de Latitude sul e entre $45^{\circ}$ $01^{\prime} 40^{\prime \prime}$ e $43^{\circ} 50$ ' 06" de Longitude oeste, como mostra a figura 1. Essa bacia possui uma área de aproximadamente $3.899 \mathrm{~km}^{2}$, a qual abrange parte dos territórios dos municípios de Montes Claros, Coração de Jesus, São João do Pacuí, Brasília de Minas, Ibiaí, Mirabela, São João da Lagoa, Ponto Chique e Campo Azul.

A população residente nesses municípios, conforme o levantamento censitário do IBGE, em 2010, totaliza 456.485 habitantes. E as principais atividades econômicas são determinadas pela pecuária, agricultura irrigada e silvicultura na zona rural e pela indústria e prestação de serviços na zona urbana (IGAM, 2006).

Devido às atividades econômicas, a bacia do rio Pacuí vem sofrendo com o uso inadequado do solo, principalmente na bacia do rio Riachão. Nesse afluente do rio Pacuí há cultivo do eucalipto e a agricultura empresarial próximos à área de nascente, o que tem trazido graves consequências para o curso d'água e para os moradores que vivem na parte baixa da bacia.

Na mesorregião Norte de Minas predomina o clima do tipo tropical sub-úmido, próximo ao limite do sub-úmido seco, com períodos de chuvas concentradas entre os meses de outubro e março, sendo que os meses de novembro, dezembro e janeiro são os mais chuvosos, enquanto que o período mais seco é o que compreende os meses de junho a agosto (NIMER; BRANDÃO, 1989).

$\mathrm{Na}$ análise das características geológicas do norte de Minas percebe-se que existe um predomínio de rochas sedimentares, identificando, em grande parte, calcários, do período Criogeniano (era Neoproterozóica). Essa formação é dividida pelo grupo Paraopeba e pela formação Lagoa do Jacaré (NPlj). 


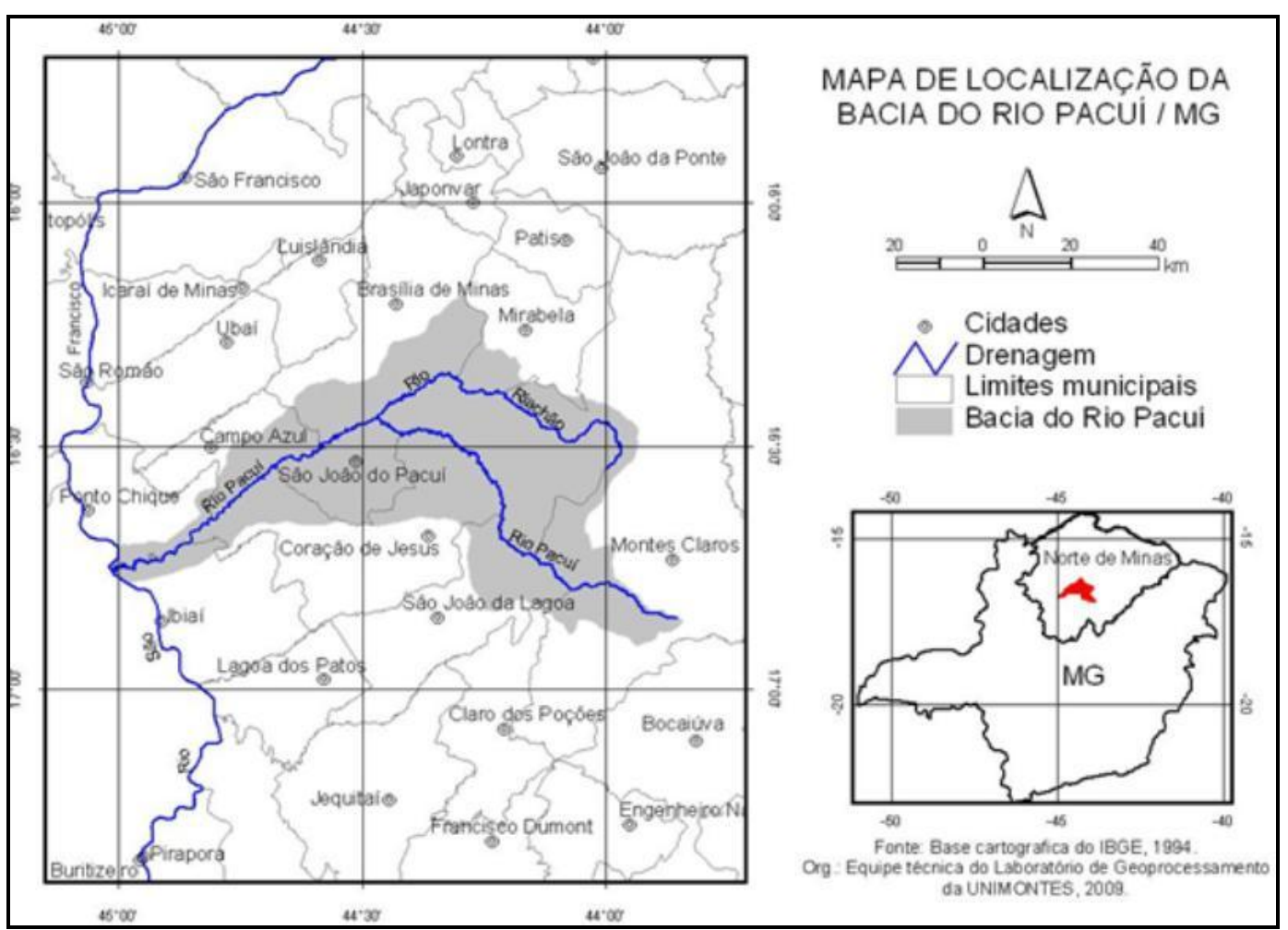

Figura 1 - Localização da bacia do rio Pacuí, no norte de Minas Gerais. Fonte: IBGE, 1994.

Como consta na figura 2, a porção oeste da bacia é caracterizada pela presença da formação Três Marias (NP3tm), especificada no conjunto litológico aglomerado, laterita e arenito arcoseano (período Ediacarano). Na porção central tem-se o grupo Urucuia (K2u) de idade cretácea, com a presença de arenito conglomerado. Discrimina-se, ainda, a leste, coberturas ferruginosas (ENdl) da era Cenozóica, caracterizadas pelos depósitos de areia, argila e cascalho (CPRM, 2003).

Já em relação à geomorfologia, a bacia está situada no domínio da depressão periférica do São Francisco com unidades caracterizadas por planaltos residuais. Predominam formas de relevo com superfícies tabulares reelaboradas por processos de erosão areolar, superfícies onduladas em planalto e superfícies aplainadas, cuja evolução está relacionada ao processo e desnudação periférica realizada pela drenagem do São Francisco. Encontram-se, também, ao longo do canal principal, formas de relevo apresentadas por vertentes ravinadas e vales encaixados (IGA, 1977). 


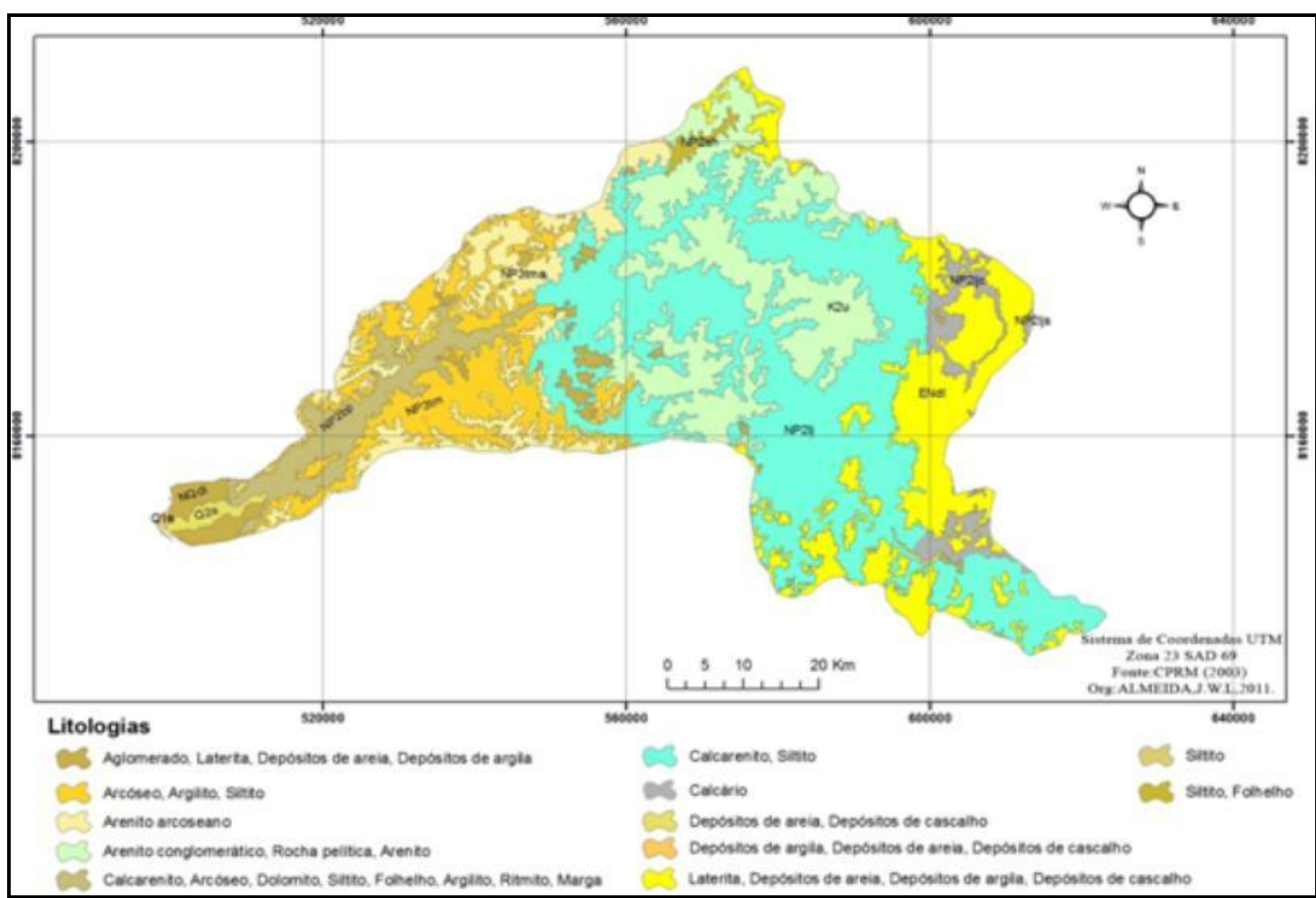

Figura 2 - Litologia da bacia hidrográfica do Pacuí.

Fonte: CPRM, 2000.

Conforme figura 3, os solos da bacia hidrográfica do rio Pacuí podem ser definidos como Latossolo Vermelho Amarelo (LVAd12), com características distrófico típico A fraco/moderado e textura média mais o Neossolo Quartzarênico Órtico típico A fraco/moderado. $\mathrm{Na}$ porção centro-oeste encontra-se Latossolo Vermelho Amarelo (LVAd21), distrófico típico A moderado textura siltosa/argilosa, pedregoso/não pedregoso. $\mathrm{Na}$ porção leste ocorre o solo Argissolo Vermelho-Amarelo (PVAe9) eutrófico típico A moderado textura argilosa. À montante da bacia tem Cambissolo Háplico distrófico típico e léptico A moderado textura média/ argilosa, pedregoso/ não pedregoso e o Neossolo Litólico. Finalmente, a jusante apresenta Neossolo Flúvico (RUbe1) Tb eutrófico típico A moderado e Gleissolo Melânico distrófico/ Gleissolo Háplico distrófico típico A moderado/proeminente (UFV, 2010).

A vegetação predominante na área de estudo é o Cerrado, Campo Cerrado, Floresta Estacional Decidual Montana, Vereda, Floresta Estacional Decidual Sub Montana. (SCOLFORO; CARVALHO, 2006). 


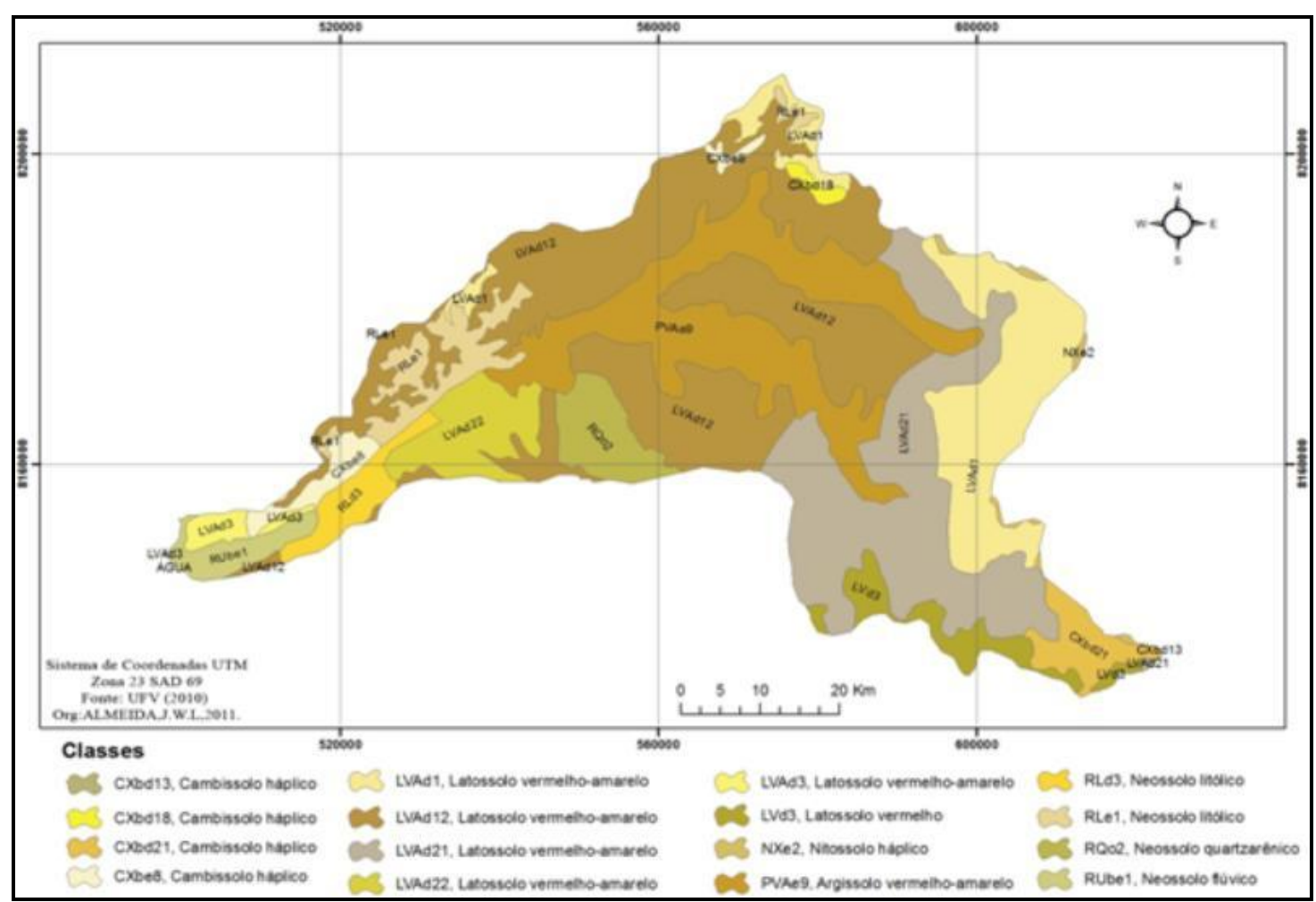

Figura 3 - Classes de solo da bacia hidrográfica do Pacuí.

Fonte: UFV, 2010.

\section{RESULTADOS E DISCUSSÃO}

A gestão da bacia hidrográfica do Pacuí, diante das suas características de uso do solo, se torna emblemática no norte de Minas Gerais, haja vista que há um conflito ambiental instalado, que tem sua origem na forma desigual de uso da água. A água, enquanto bem público, deve ser distribuída igualmente para seus usuários, porém essa diretriz legal não está sendo praticada na bacia do Pacuí (AFONSO, 2008).

Os usos do solo para diversos fins, como a plantação na monocultura do eucalipto, cultivo, pastagem e outros, requerem uma modificação do espaço natural da bacia. Isso ficou perceptível no referido estudo nos anos de 1989, 1999 e 2009, no qual foram observadas as mudanças na área da bacia durante os períodos analisados.

Dentre as atividades correntes no Norte de Minas Gerais, que trazem grandes impactos no ecossistema natural, estão: a) a implantação da monocultura do eucalipto; b) a produção de carvão vegetal, visando o abastecimento das usinas de minério de ferro na região central do estado - o que provocou uma devastação da vegetação nativa; c) a manutenção da pecuária extensiva - que também provoca o desmatamento, inclusive das matas ciliares; d) os 
projetos de implantação da irrigação mecânica; e) o desperdício de água e outros (AFONSO, 2008).

Com os procedimentos metodológicos adotados e os estudos realizados obtiveram-se os seguintes resultados, como pode ser verificado na figura 4. No ano de 1989, a área de vegetação natural ocupava cerca de $2.725,52 \mathrm{~km}^{2}$, o que corresponde aproximadamente, a $70 \%$ do total da bacia, com relação à vegetação natural. O bioma predominante nesta área é o cerrado e suas demais feições, sendo encontrado em toda a área da bacia. A pastagem ocupava, neste mesmo período, $825,12 \mathrm{~km}^{2}$, o que corresponde a $21 \%$ do total da bacia hidrográfica. A classe "Outros", que agrupa pastagem degradada e solo exposto, no ano de 1989, abrangia aproximadamente $117,11 \mathrm{~km}^{2}$, o que corresponde a $3 \%$ do total da bacia. A classe do Eucalipto obteve $228.15 \mathrm{~km}^{2}$ de área e o Cultivo $2.72 \mathrm{~km}^{2}$. Estes usos juntos corresponderam a $6 \%$ da área da bacia, sendo que elas estavam mais concentradas na parte alta, principalmente próximo à nascente do rio Riachão.

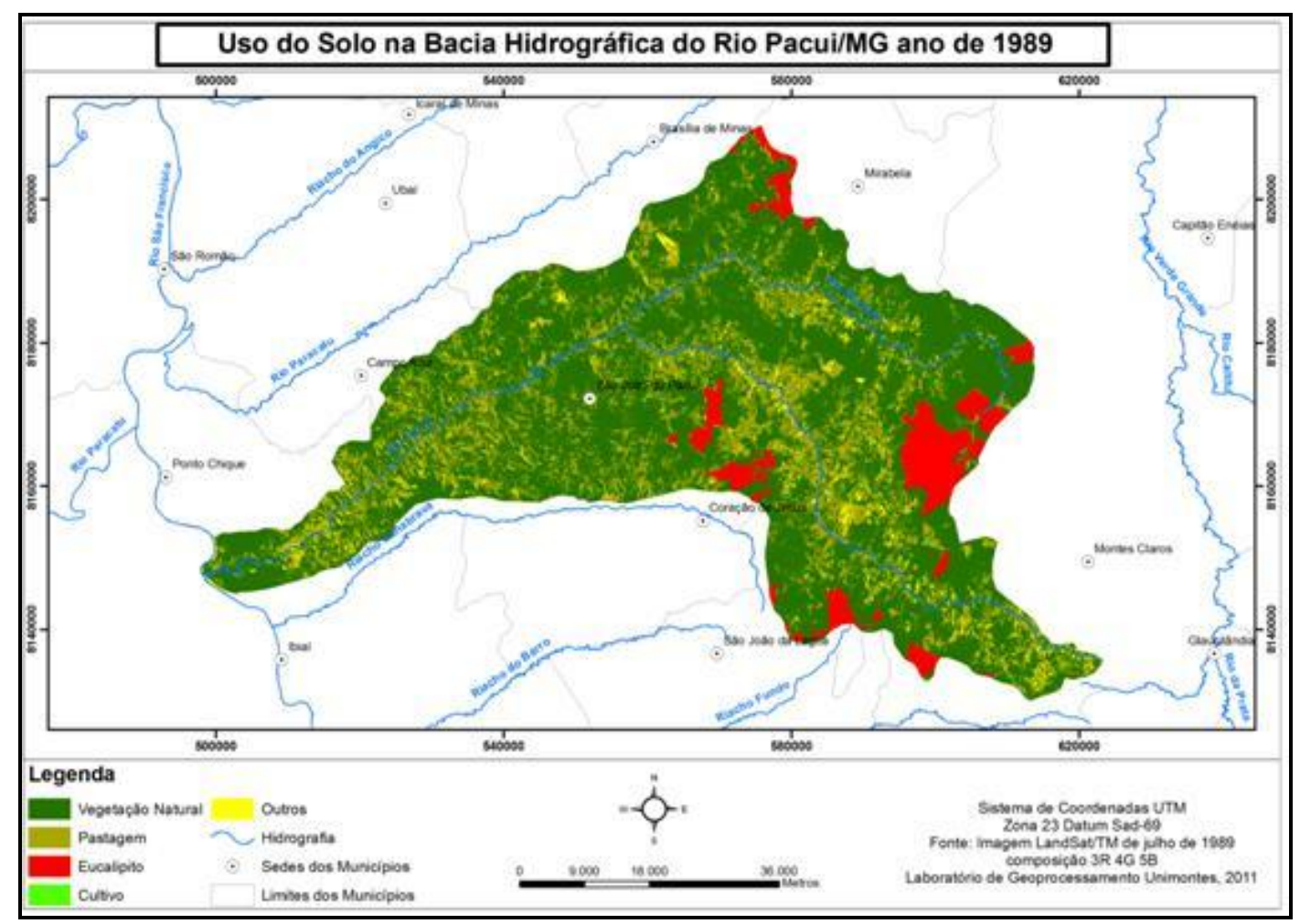

Figura 4 - Uso do solo na bacia Hidrográfica do rio Pacuí/MG - 1989.

Fonte: Imagem LandSat, 1989.

Tendo como base o ano de 1999, a figura 5 mostra que a área ocupada pela vegetação natural ocupava $2.357,34 \mathrm{~km}^{2}$, que corresponde a aproximadamente $60 \%$ do total da bacia. Em relação a 1989 observa-se uma redução de 10\% desta classe, em relação à área total. A 
pastagem apresentou uma área de $972,58 \mathrm{~km}^{2}$, o que representa um crescimento de $18 \%$, comparado com o ano de 1989. A classe "Outros" abrangia $303 \mathrm{~km}^{2}$, a qual apresentou um crescimento de $159 \%$. O eucalipto estava com $254.64 \mathrm{~km}^{2}$ de área e a classe de "Cultivo" com 5,66 $\mathrm{km}^{2}$. Dessa maneira, percebe-se que as atividades antrópicas aumentaram entre 1989 e 1999, trazendo impactos ao meio natural, como na vegetação e nos cursos da água, agravando assim, a tensão pela disputa da água na bacia do rio Pacuí.

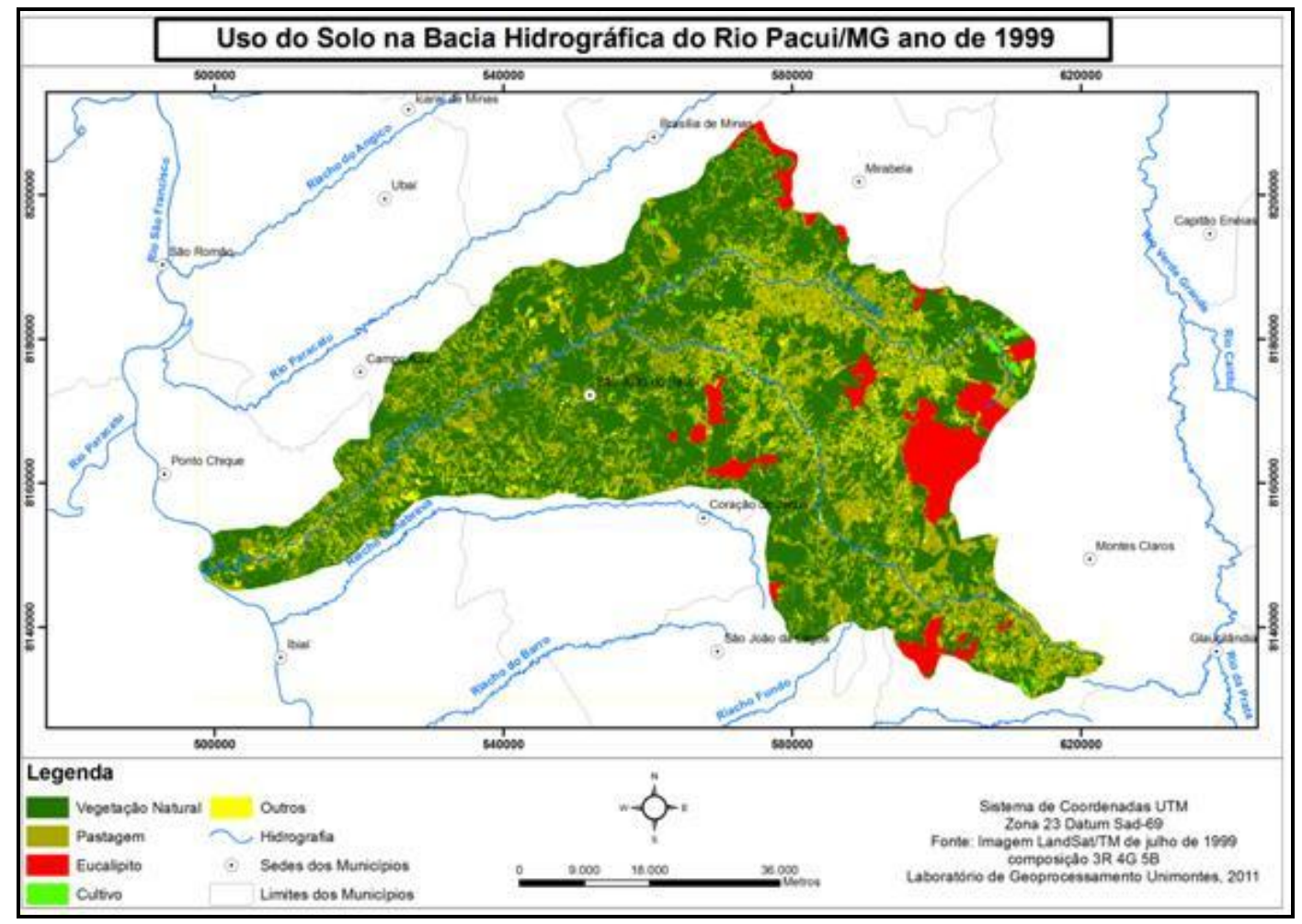

Figura 5 - Uso do solo na bacia Hidrográfica do rio Pacuí/MG - 1999.

Fonte: Imagem LandSat, 1999.

Analisando os dados do mapeamento de 2009, expostos na figura 6 , observa-se que a vegetação natural apresentou uma área de $2048.82 \mathrm{~km}^{2}$, o que equivale a aproximadamente $52 \%$ do espaço total da bacia. Com isso, houve uma redução de $24,5 \%$ em relação ao ano de 1989, tendo como agravante a supressão da mata ciliar para outros usos como pastagem e cultivo.

É importante salientar que há uma legislação que proíbe a supressão de áreas de Área de Preservação Permanente (APP). O Código Florestal instituído pela Lei n. 4.777/65 estabelece que toda a vegetação natural presente ao longo das margens dos rios e ao redor de nascentes e de reservatórios deve ser preservada. De acordo com o artigo $2^{\circ}$ da Lei $n$. 4777/65 e com as alterações oriundas da Lei n. 7.803/89, a largura da faixa da mata ciliar a 
ser preservada está relacionada à largura do curso d'água e não deve ser inferior a 30 metros. Porém, mesmo com a garantia legal, esta vegetação é suprimida para atividades de diversos fins, que ocasionam degradações em variados níveis na área.

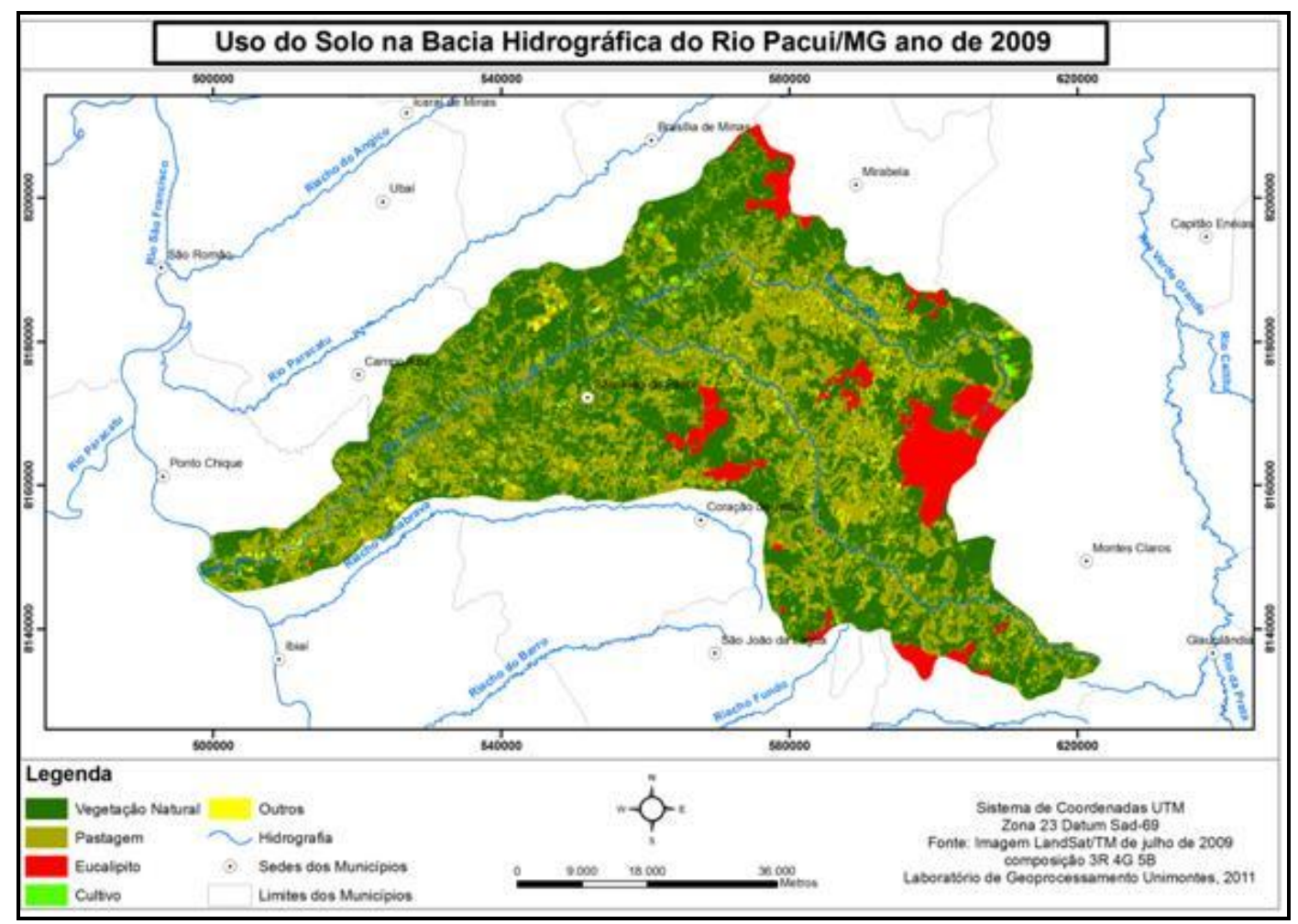

Figura 6 - Uso do solo na bacia Hidrográfica do rio Pacuí/MG - 2009.

Fonte: Imagem LandSat, 2009.

O uso do solo para pastagem demonstrou aumento significativo. No ano de 2009 , os dados mostraram que a área destinada ao pasto era de $1.333,15 \mathrm{~km}^{2}$, ou seja, $34 \%$ da bacia. Ao longo de 20 anos houve um aumento de 13\%. A retirada da vegetação natural para o plantio de pastagem implica em várias formas de degradação ambiental, como a diminuição da biodiversidade, o sobrepastoreio que aumenta a erodibilidade do solo, intensificando os processos erosivos.

As classes de eucalipto e cultivo apresentaram uma área de $7 \%$ no ano de 2009 , mantendose estável nos períodos analisados, sendo mais concentradas no alto da bacia do rio Riachão, nas proximidades da lagoa da Tiririca.

A figura 7 mostra a evolução dos dados de áreas das classes de uso do solo por período de análise. Essa comparação evidencia que a vegetação natural perdeu espaço, principalmente para a pastagem. Além da pastagem, o eucalipto apresentou uma sensível expansão de área. A classe de solo exposto e pastagem degradada, denominada como Outros, também cresceu 
ao longo do período analisado. Esse fato está associado à pecuária extensiva que provoca a degradação do solo, com o sobrepastoreio e a intensificação da erosão.

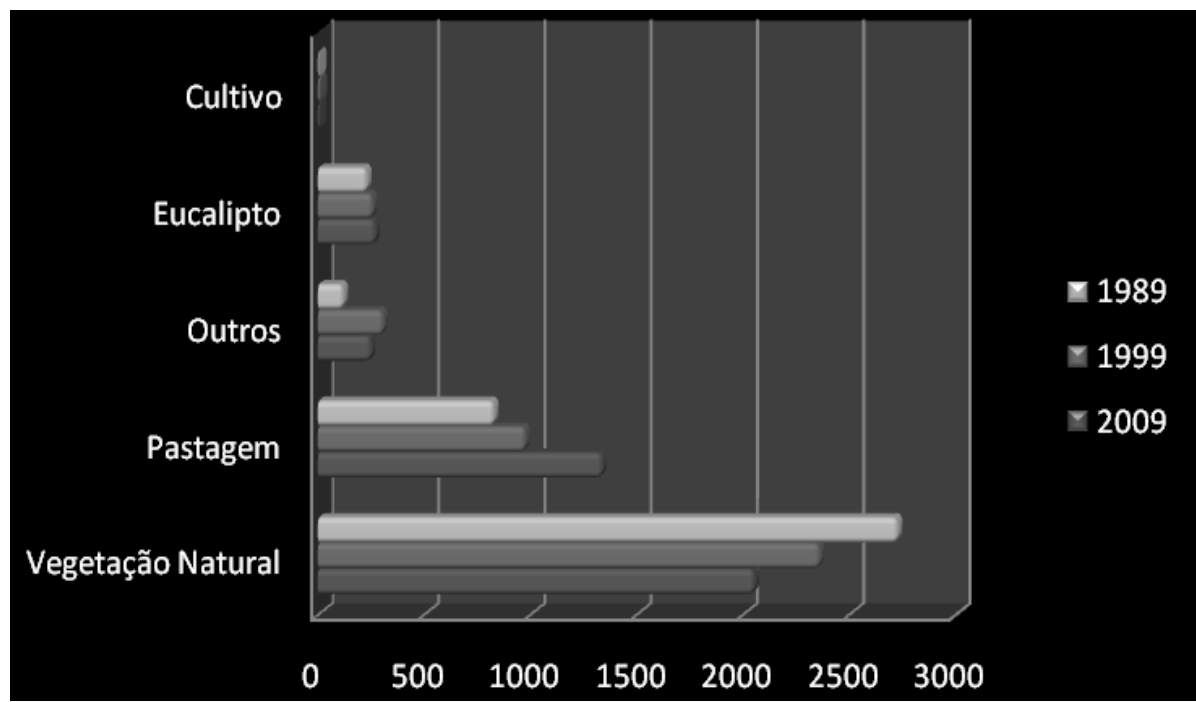

Figura 7 - Uso do solo na bacia do rio Pacui em 1989, 1999 e 2009.

Fonte: Imagens LandSat dos anos 1989, 1999 e 2009.

Os dados apresentados apontam que o principal uso antrópico na bacia do Pacuí é a pastagem, haja vista que se trata de um espaço de concentração de fazendas destinadas a criação de bovinos, de maneira extensiva.

Diante dos resultados obtidos pela classificação das imagens, observou-se que a exploração do solo na bacia do rio Pacuí teve significativo aumento no período analisado, implicando na não preservação dos recursos naturais, uma vez que determinados usos tendem a ocupar áreas cada vez maiores. Logo, a partir da análise do uso da terra e de relato de moradores foi observado que a forma de exploração do solo tem afetado a disponibilidade hídrica na bacia em questão, principalmente à montante, onde está a sub-bacia do rio Riachão.

\section{CONSIDERAÇÕES FINAIS}

Os dados deste trabalho, obtidos a partir de sensor remoto, mostraram que a ocupação na bacia do rio Pacuí se intensificou, ao longo das duas últimas décadas, principalmente com a expansão da pecuária extensiva que provocou o crescimento da área de pastagem. Com isso, houve supressão da vegetação natural, sendo que a parte alta da bacia, onde se encontra a nascente do rio Riachão, é o local com menor percentual de preservação da vegetação. As 
visitas a campo permitiram identificar indícios da degradação do solo, em alguns pontos da bacia, como presença de processos erosivos.

Esses usos da terra identificados, principalmente próximo às nascentes, afetam diretamente a disponibilidade hídrica da bacia. O conflito de água no rio Riachão é uma consequência direta do uso irracional da água superficial. Essa situação levou o poder judiciário, através da Promotoria de Justiça, a intervir, exigindo a preservação da nascente do rio Riachão, como fim da instalação de pivô e o controle da visitação.

Esses dados servem de alerta para a situação ambiental da bacia do rio Pacuí, que é um importante afluente do São Francisco, no norte de Minas Gerais. A série cronológica de mapas mostrou a dinâmica do uso do solo e denunciam que ao longo dos anos a vegetação natural perdeu espaço para as atividades econômicas exercidas.

Nesse contexto, é recomendável a adoção de estratégias de gerenciamento, com novas formas de regularização dos diversos usos dos recursos, diminuindo assim os impactos ambientais da bacia.

\section{AGRADECIMENTOS}

Os autores agradecem a FAPEMIG pelo apoio financeiro e pelas bolsas de pesquisa e de iniciação científica.

\section{REFERÊNCIAS BIBLIOGRÁFICAS}

AFONSO, P. C. S. Gestão e Disputa pela Água na Sub-Bacia do Riachão, Montes Claros/MG. 146 p. Uberlândia: UFU, 2008. Dissertação (Mestrado) - Programa de Pós-Graduação em Geografia, Universidade Federal de Uberlândia, 2008.

BRASIL. Lei $n^{\circ} 4.777$, de 15 de setembro de 1965. Institui o novo código florestal. Disponível em: http://www.planalto.gov.br. Acesso em: 15/03/2011.

BRASIL. Lei no 7.803 de 18 de julho de 1989. Altera a redação da Lei $n^{\circ} 4.771$, de 15 de setembro de 1965, e revoga as Leis $n^{\circ}$ 6.535, de 15 de junho de 1978, e 7.511, de 7 de julho de 1986. Disponível em: http://www.planalto.gov.br. Acesso em: 15/03/2011.

CHRISTOFOLETTI, A. Geomorfologia. São Paulo: Edgard Blücher, 1974. 
CUNHA, S. B. da.; GUERRA, A. J. T. (Org.). Avaliação e perícia ambiental. 2a ed. - Rio de Janeiro: Bertrand Brasil, 2000.

CPRM. Mapa Geológico do Estado de Minas Gerais. 2003. Disponível em: http://www.cperm.gov.br/. Acesso: 03/09/2011.

IGA, Instituto de Geociências Aplicadas. Mapa Geomorfológico - Folha Montes Claros-MG, 1997. Escala: 1:500.000.

IGAM, Instituto Mineiro de Gestão das Águas, 2006. Projeto Proágua / Semiárido -Primeira Etapa do Plano Estadual De Recursos hídricos de Minas Gerais. Relatório Técnico 2. Contrato Agência Nacional de Águas - ANA, Governo do Estado de Minas Gerais, Contrato n 010/2006, Setembro/2006.

McCLOY, K. R. Resource Management Information Systems: remote sensing, GIS and modeling. 2. ed. Boca Raton: Taylor and Francis, 2005.

NOVAES, W.; RIBAS, O.; NOVAES, P. da C. (Coord.); Agenda 21 Brasileira - Bases para discussão. Brasília: MMA/PNUD, 2000.

NIMER, E.; BRANDÃO, A. M. P. M. Balanço Hídrico e Clima da região do Cerrado. Rio de Janeiro, IBGE, 1989.

ROSA, R. Introdução ao sensoriamento remoto. 6. ed. Uberlândia: EDUFU, 1995.

SCOLFORO, J. R. S.; CARVALHO, L. M. T. Mapeamento e Inventário da Flora Nativa e dos Reflorestamentos de Minas Gerais. Lavras: IEF/UFLA, 2006.

TUNDISI, J. G. Água no século XXI: enfrentando a escassez - 2ae ed.- São Carlos: Rima, 2005.

UFV, Universidade Federal de Viçosa - Departamento de solos - DPS/LABGEO. Mapa de Solos do Estado de Minas Gerais, 2010. Escala 1: 600.000.

\section{Artigo recebido em 05/01/2012.}

\section{Artigo aceito em 03/02/2012.}

